the fact that in $1770-1773$, Lagrange published an elaborate memoir at Turin under the title "Mémoire sur l'utilité de la Méthode de prendre le Milieu entre les resultats de plusieurs Observations," \&c. Vide "Euvres de Lagrange," edited by J. A. Serret, vol. 2.

I have never seen any notice of this memoir except a translation of a part of it into German by Encke, published in the Berliner fahrbuch for 1853 . Thus in the abstract of a memoir by Mr. J. W. L. Glaisher, given in the notices of the Royal Astronomical Society for April 1872, the name of Lagrange does not occur.

I think that the English mathematician, Thomas Simpson, busied himself with this problem about $175^{\circ}$, but I am not able to refer to his works.

Washington, May 22

\section{The Volcanoes of Central France}

AN unlucky error, perhaps nine, in the letter on the "Volcanoes of Central France," p. 8o, will quite prevent any reader finding the paper I mentioned of May 1865, which, instead of being in the Gentleman's Magazine, was in the Enolish. man's Magazine, a short-lived periodical, begun and ended, I think, with that year. As your two correspondents, Prof. Corfield and the Rev. Mr. Webb, like the writer of that paper, repeat the late Dr. Daubeny's most marvellous "conclusion" that there might have been nothing more eruptive in the phenomena than "bursting out of flames "from earthquake fissures, and even that the fires mentioned by Sidonius and Avitus might be "domestic conflagrations," may Ibriefly indicate the grounds that make these suppositions to me incredible? These fires, as named in the portions of each document that I have translated-quite distinct from the conflagration of some public building on the Easter festival of a previous year, which both writers afterwards relate at greater length as an earlier and less known case of successful prayer by Mamertus, the memory of which had encouraged him under these "prodigies" and "portents," the isnes (not incendia) that both writers make a chief or the chief part of the "terrors"-(Sidonius, indeed, names the earthquakes before them, but Avitus twice over puts the fires first)-these were crebri and ctssidui, continual for two or three years, yet not a word of what they fed on or what valuables they destroyed, and they were only sape fammati. Their being so sometimes is plainly named by Sidonius as an unusual and greater portent. Now, I never heard of any "domestic" fires that were not "flammati," whereas volcanic eruptions, even severe, seldom if ever involve flame truly so called, though their strongly illuminated smoke may often by night be mistaken for flames, and has led them to be called in extreme cases, as Sidonius here said, sape flammati. $\mathrm{He}$ adds that when thus "flammati" they did, or rather threatened to do, the only mischief named as even apprehended from them at the capital, the endangering frail roofs by a load of ashes thrown over, superjecto farillarum monte. Now, surely this is not an effect of any ædile conflagrations however often repeated (a repetition that would anywhere have been regarded rather as suspicious of incendiarism than as "prodigious" and preternatural). Nor would any such accidents lead Avitus to ask in his sermon to those who remembered all, "Who would not dread the Sodomitic showers?" Again, Mr. Webb conceives that earthquakes might not only drive the wealthier part of the population out of the city, "but, as it would seem, the beasts into it!" I never heard of shocks producing so singular an effect as driving any living thing into cities or buildings, and cannot conceive what natural event could so drive them, unless what is here by both witnesses implied, "Sodomitic showers" of hot or cumbering favilla. Such showers, which we know to be often carried, from eruptions involving no lava, scores or even hundreds of miles, in the direction of the prevailing winds, would be carried from any of the well-known cones of the Forèz or Vivarais, towards, or even far beyond, Vienne ; and wild animals, fleeing north-eastward, would have no refuge but under roofs; and if private house doors were habitually shut (as now in England) might crowd into the colonnades (fori latera) of that capital city. This incursion of the wild deer, bears, and wolves into towns was so well remembered as to become, in the later chroniclers, Gregory of Tours, \&c., dwelt upon among the main "prodig es" of the time, along with the earthquakes and burnings of buildings, though any other fires cease to be implied; and the reason of this is obvious on comparing their accounts.
They all copy one another, and the earliest, whose sole authorities were those two pompous and involved writers, mis-read them exactly as our moderns (except Sir F. Palgrave) appear to have done, confusing together the fires of the "prodigies," that led to the Rogation fasts with the earlier adile conflagration at some Easter, said to have been prayed out by Mamertus, which occupies both the writer and preacher immediately after, and at greater length than these well-known "terrors" remembered by those they addressed personally.

The whole strikingly shows, as Sir F. Palgrave said, the fallacy of geological inferences from the "silence of history" (or what may be deemed silence) in times and places practically prehistoric, or at least preter-historic. He showed that, but for Pliny and a mere accident, we should probably have been as ignorant of even the Pompeii and Herculaneum eruption as of these equally attested ones. Again, the Spaniards would have preserved us no memory of the rise of Jorullo, in the very last century; and yet probably no part of Gaul in the generation when the Romans lost it was really more settled and populous than Mexico in its third century of Spanish rule. The only important colonies within moderate shower-range of the eastern volcaroes were Vienne and Lyons, the latter farther off, and not at that time a capital, indeed but little heard of in those early middle ages. And fires, not called damaging, only "prodigious" and terrifying to Vienne, and causing "Sodomitic showers" there, need not have been within a few miles, but far in the wilds, then hardly trodden, of its mountainous south-western horizon.

$$
\text { 7, Mornington Road, N.W., June I }
$$

\section{E. L. GarbetT}

\section{Temperature of the Deep Sea}

WILL you allow me to ask, through your pages, if there be any rule for ascertaining the temperature of the sea at given depths below the surface? To practical electricians such a rule would be very valuable.

I will state a case. There is a submarine cable connecting two stations, $A$ and $B, 150$ miles distant. The temperature at $\mathrm{A}$ is $75^{\circ} \mathrm{Fah}$; that at $\mathrm{B}, 68^{\circ} \mathrm{Fah}$.; and the average depth at which the cable lies 120 fathoms: what is the average temperature of the cable?

If you could refer me to any work in which this point is treated I shall be obliged.

\section{ENDOWMENT OF PROFESSORSHIPS}

THE following correspondence between Professors $\mathrm{H}$. E. Roscoe and B. Stewart, of Owens College, Manchester, and the Chancellor of the Exchequer, is published in the Times of Monday last :-

\section{"TO THE RIGHT HON. ROBERT LOWE, CHANCELJoR OF THE EXCHEQUER. \\ "Owens College, Manchester, May 2r, I862.}

"Sir,-In the Times of May I7 you are reported, at the presentation for Degrees at the University of London, to have pointed out 'how the endowment of Professorships naturally tended to make teaching inefficient (seeing that the revenues come in independently of the results of teaching), suggesting that those who had any money to spare for the advancement of education should rather make it available in the forms of Scholarships and Exhibitions.'

"While we gratefully acknowledge the many services which, as Chancellor of the Exchequer, you have rendered to the cause of knowledge, we yet feel most strongly that the above expressions are calculated to mislead, and that were your suggestions to be carried out, the result would be fatal to the higher education of this country.

"We therefore request permission to lay before you our own views on this most important subject. Writing from the very house once inhabited by Cobden, we feel proud to be connected with a city which was the birth-place of Free Trade; yet we feel equally privileged to form part of a very useful institution which never could have existed 